\title{
Erratum to video-assisted thoracoscopic versus open thoracotomy lobectomy: a Swedish nationwide cohort study
}

\author{
Mamdoh Al-Ameri ${ }^{1,2}$, Per Bergman ${ }^{1,2}$, Anders Franco-Cereceda ${ }^{1,2}$, Ulrik Sartipy ${ }^{1,2}$ \\ ${ }^{1}$ Heart and Vascular Theme, Karolinska University Hospital, Stockholm, Sweden; ${ }^{2}$ Department of Molecular Medicine and Surgery, Karolinska \\ Institutet, Stockholm, Sweden \\ Correspondence to: Ulrik Sartipy, MD, PhD. Heart and Vascular Theme, Karolinska University Hospital, SE-171 76 Stockholm, Sweden. \\ Email: Ulrik.Sartipy@karolinska.se.
}

doi: $10.21037 /$ jtd.2020.02.45

View this article at: http://dx.doi.org/10.21037/jtd.2020.02.45

Erratum to: J Thorac Dis 2018;10:3499-506.

Video-assisted thoracoscopic versus open thoracotomy lobectomy: a Swedish nationwide cohort study

This article that appeared on Page: 3499-3506, Vol 10, No 6 (June 2018) Issue of the Fournal of Thoracic Disease (7TD) (1), a numerical error occurred in the following sentence:

"We also excluded a very small number of patients (n=14) who underwent VATS lobectomies at the other hospitals in Sweden during the study period."

The correct number should be ( $\mathrm{n}=174)$ and the sentence should read:

"We also excluded patients (n=174) who underwent VATS lobectomies at the other hospitals in Sweden during the study period."

This numerical error does not affect the results or conclusions of the study because the number indicates a group of patients that were excluded from the study.

The authors regret the error.

Open Access Statement: This is an Open Access article distributed in accordance with the Creative Commons AttributionNonCommercial-NoDerivs 4.0 International License (CC BY-NC-ND 4.0), which permits the non-commercial replication and distribution of the article with the strict proviso that no changes or edits are made and the original work is properly cited (including links to both the formal publication through the relevant DOI and the license). See: https://creativecommons.org/licenses/by-nc$\mathrm{nd} / 4.0 \%$.

\section{References}

1. Al-Ameri M, Bergman P, Franco-Cereceda A, et al. Video-assisted thoracoscopic versus open thoracotomy lobectomy: a Swedish nationwide cohort study. J Thorac Dis 2018;10:3499-506.

Cite this article as: Al-Ameri M, Bergman P, Franco-Cereceda A, Sartipy U. Erratum to video-assisted thoracoscopic versus open thoracotomy lobectomy: a Swedish nationwide cohort study. J Thorac Dis 2020;12(4):1645. doi: 10.21037/jtd.2020.02.45 